\title{
Can sarcopenia index serve as a predictor of myocarditis from mRNA based COVID-19 vaccine, insights from clustered cases and potential involvement of micro-RNAs in its pathogenesis.
}

Antoine AbdelMassih ( $\square$ antoine.abdelmassih@kasralainy.edu.eg )

Meryam El Shershaby

Hanya Gaber

Habiba-Allah Ismail

Nadine El-Hussseiny

Abeer Amin

Aly ElBoraie

Aya Ayad

Esraa Menshawey

Fady Sefein

Ibrahim Osman

Mai Moursi

Maram Hanafy

Mariam AbdelAziz

Mariem Arsanyous

Mariam Khaled-Ibn-El-Walid

Marwa Tawfik

Menna Habib

Mina Mansour

Mirette Ashraf

Mohamed Khattab

Nada AlShehry

Nada Hafez

Naheel Essam ElDeeb

Nivana Ashraf

Noha Khalil

Noheir AbdEISalam

Noura Shebl

Nouran Hafez

Nourhan Youssef

Odette Bahnan

Passant Ismail

Peter Kelada

Rahma Menshawey 
Rana Saeed

Reem Husseiny

Reem Yasser

Safa Sharaf

Veronia Adel

Youstina Naeem

Youstina Nicola

Aya Kamel

Rafeef Hozaien

Raghda Fouda

\section{Systematic Review}

Keywords: mRNA vaccines, COVID-19, micro-RNAs, Sarcopenia index

Posted Date: November 8th, 2021

DOI: https://doi.org/10.21203/rs.3.rs-1036153/v2

License: (9) (1) This work is licensed under a Creative Commons Attribution 4.0 International License. Read Full License 


\section{Abstract}

Background:

With the current mass international roll out of several vaccines against SARS-Cov-2, several reports of unheeded complications have made headlines. One of which involves myocarditis with the now FDA fully approved vaccine, Pfizer, and others.

We hypothesize through this study that a dysregulated micro-RNA response resulting from such type of vaccines can be involved in triggering myocarditis.

Methodology:

Embase, Medline and the Cochrane Central Register were used to search for specific keywords such as "mRNA COVID-19 vaccines" AND "Myocarditis" for relevant publications up to 1st of September 2021. The systematic review was performed using PRISMA protocol

Results:

Literature review has identified 26 cases series and reports involving the development of myocarditis from mRNA vaccines, a total of 89 patients were included. Age range was clearly identified in 66 patients. Among those 66 patients, $94 \%$ were below 50 years of age, also out of 89 patients, $94 \%$ were males. Myocarditis developed, after a median time of 72 hours of the $2^{\text {nd }}$ dose. 90 of cases of myocarditis developed myocarditis after the $2^{\text {nd }}$ dose, the few patients developing myocarditis after the first dose were either predisposed by a history of myocarditis or a history of previous COVID-19 infection.

Conclusion:

In conclusion, interpretation of the results in view of the suggested hypothesis, reveals that the micro-RNAs implicated in myocarditis in general are as well implicated in the pathogenesis of severe COVID-19, this can explain why patients having a first dose with a history of COVID-19 can develop myocarditis from mRNA vaccines, also the relatively higher likelihood of this complication in males and younger aged individuals can be explained by the upregulation of key myocarditis related miRNAs in those two strata, due to higher muscle mass and suggests performing a sarcopenia index in recipients of the vaccine to correlate it with the likelihood of this complication. This could later set a cut-off of this easy bed-side index to stratify cases a higher risk of this rare complication.

\section{Background}

COVID-19 is the largest and deadliest pandemic to strike the globe to date. Since its beginning in China and Asia in 2019, it has led to the loss of many lives up to this day. The resultant global health crisis has compelled health authorities all over the world to provide emergency authorization to many vaccines, well before full FDA approval. This accelerated vaccine rollout in late 2020 has greatly reduced the incidence of severe COVID-19 complications, and hospitalizations.(1) However, a major setback of such emergency authorization was the rise of unexpected complications, such as HIT-like syndrome from adenovirus-based vaccines. (2)One of the most serious complications of the COVID-19 vaccines was post vaccination Myocarditis associated with the mRNA 
vaccines. Myocarditis is a rare complication, which was more commonly occurring in young adults and adolescents. (3)As mentioned by Bozkurt et al, according to the US centers for disease control and prevention, Myocarditis/Pericarditis rates are $=12.6$ cases per million doses of second dose mRNA vaccine among individuals 12 to 39 years of age.(4) Interestingly, there is absence of reported cases of Myocarditis with nonmRNA vaccines such as Janssen.

Several mechanisms were suggested as to why the mRNA vaccines specifically lead to myocarditis. One hypothesis is that mRNA vaccines generate a very high antibody response, like multi- system inflammatory syndrome in children. Molecular mimicry between the protein of SARS-CoV-2 and self-antigens triggering an abnormal immune response has been proposed.(4) In this article we propose a totally different hypothesis related to micro-RNAs. MicroRNAs are short non-coding RNAs that play a crucial role in the regulation of gene expression during cellular processes. It is now established that some of the host-generated miRNAs are known to modulate the antiviral defense during viral infection. Recently, multiple DNA and RNA viruses have been shown to produce miRNAs known as viral miRNAs (v-miRNAs). We hypothesize that mRNA vaccines can either trigger the release of host miRNAs or contain themselves some miRNAs that can trigger this unwanted complication. This suggested hypothesis can have critical diagnostics and therapeutic implications.

\section{Methodology}

Embase, Medline and the Cochrane Central Register were used to search for specific keywords such as "mRNA COVID-19 vaccines" AND "Myocarditis" for relevant publications up to 1st of September 2021. The systematic review was performed using PRISMA protocol

\section{Results}

To date, 26 cases' series of myocarditis cases from mRNA vaccines have been reported, comprising a total of 70 cases. Table 1 summarizes the main characteristics of those cases(5)(6) (7) (8) (9) (10) (11)(12) (13) (14) (15)

(16)(17) (18) (19) (20) (21) (22) (23) (24) (25) (26) (27) (28) (29) (30)

The collected cases series and reports comprised in total 89 cases. A quick analysis of the reported cases reveals that among cases or case series where recipients' ages were reported in details (66 cases out of 89 ), only 4 cases were above the age of 50 years while the remainder were below 50 years of age (Figure 1). Among the 89 cases, only 5 were females (Figure 2). Finally, yet importantly, $90 \%$ of patients (80) developed myocarditis after the second dose. 5 out of 9 patients developing myocarditis from the first dose had history of COVID-19 infection, while 2 had history of myocarditis from another viral illness and the remainder developed it after 7 and 16 days respectively from the first dose which is longer than the median time of development of myocarditis in other cases (72 hours). (Figure 3 )

\section{Discussion}

A)Viruses inducing myocarditis alter host micro-RNAs expression

Many studies have identified several miRNAs that have a direct relationship with myocarditis. 94 types of miRNAs were studied using gene microarray analysis during viral myocarditis; 27 of which were downregulated 
and 67 were upregulated during myocarditis in comparison with the controls. One of the miRNAs, called miRNA214 was found to be elevated in plasma during myocarditis. They promote cardiac inflammation by increasing the expression of TNF alpha and IL-6. Their presence in plasma could guide us towards using it as a noninvasive biomarker for diagnosing myocarditis.(28)

Many studies are suggesting the therapeutic role of microRNA in myocarditis. For example, the role of microRNA-155 in viral myocarditis caused by Coxsackievirus was explained, and macrophage infiltration was found to be a hallmark feature of viral myocarditis. As studies have shown that microRNA-155 regulates the differentiation of macrophages, it was found that silencing the microRNA-155 found in cardiac muscles through affecting macrophage polarization and shifting the inflammatory mediators balance, resulted in increased levels of alternatively-activated macrophages (M2) and decreased levels of classically-activated macrophages (M1) in the heart, which will decrease risks associated with viral myocarditis as cardiomyopathy and heart failure and thus, may be a potential therapeutic target for viral myocarditis. This gives genetic evidence about the role of endogenous miR-155 in modulating macrophage polarization and protecting mice that were experimented on by CVB3-induced VM. $(29,30)$

Another study by Corsten et al revealed that antimiR-155 therapy in VM (Viral Myocarditis) decreased monocytemacrophages numbers and suppressed T-lymphocyte activation, along with inhibition of release of both proand anti-inflammatory cytokines, including TNF- $a, I I-6, I L-10$, and IFN- $y$ during the inflammatory phase. Furthermore, suppression of miR-155 reduced body weight loss caused by systemic illness, along with the numbers of circulating leukocytes induced by CVB3 infection. In addition to miRNA-155, miR-146b and miRNA21 were constantly upregulated during acute inflammation of both human and mouse VM that all contribute to the immune response and inflammatory process(29). miRNA 21 inhibits the pathway of inflammatory NF-KB and antagonizes cardiac myocyte apoptosis in miRNA 21 gene carriers(31). CVB3-upregulated miR-21 can cause heart muscle cell damage by disrupting cardiomyocyte interactions through depressing the levels of components in cell-cell interactions related to the cardiac function. Therefore, during the CVB3 infection, miR-21 expression may lead to the pathogenesis of VMC, and its suppression can reduce host injury(32) It is suggested to prepare miRNA21 mimics for achieving a cardioprotective mechanism. While to antagonize the suppressive effect of proinflammatory miRNAs, some prepared nucleotides were suggested as possible future inhibitors for proinflammatory miRNAs, namely anti-miRNAs oligonucleotides AMOs, antagomirs, locked nucleic acid LNA, antisense nucleotides, peptide nucleic acids and miRNA sponges. $(30,33,34)$

Furthermore, CVB3 reduces the expression of miR-21 which directly inhibits Programmed cell death 4 (PDCD4) resulting in non-stopping apoptosis and worsened myocarditis. CVB3 also cause miR-20b to repress ZFP-148; which is responsible of viral replication, while aberrant miR-20b increases anti-apoptotic proteins $\mathrm{B}$ cell lymphoma-2 (Bcl-2) and B-Cell lymphoma-extra large (Bcl-xl)(35). This shows that CVB3 tends to induce miRNAs that balance cardiac cell survival versus apoptosis to create an optimal environment for the virus to replicate. Interestingly, miR-590-5p released extracellularly by CVB3 inhibited pro-apoptotic factors, resulting in prolonged viral replication. Similarly, miR-98 (which can regulate cell apoptosis by interacting with FAS/FASL gene pair) was found to be downregulated in myocarditis patients. Adenosine deaminases acting on RNA bind with Dicer to increase miRNA-222 which inhibits expression of the gene responsible for PTEN (an apoptosis 
associated protein) during CVB3 induced myocarditis. This shows that non-coding RNAs are important in determining cell fate in enteroviruses infection(36-38).

Another example concerning apoptosis is the miR-29 family's downregulation which has been linked to the pathophysiology of tissue scarring, including heart disease. miR-29b was found to be down-regulated in people and animals with atrial fibrillation or congestive heart failure, and miR-29b protected against Angll-induced hypertensive cardiac remodeling via inhibiting the TGF/Smad3 signaling pathway. By modifying the extracellular matrix (ECM) and correcting erroneous promoter methylation, it also inhibited cell proliferation and migration. TUG1 taurine up-regulated gene was found to be adversely regulating miR-29b in this study. Overexpression of miR-29b altered TUG1's effect on cell apoptosis and inflammation, suggesting that miR-29b may have a pro-apoptotic and pro-inflammatory effect in LPS-damaged H9c2 cells(39).

Another example of miRNA being therapeutic is the fact that androgen receptors were found to be involved in increasing cardiac fibrosis through affecting micro RNA125b (mir-125b) by stimulating more collagen synthesis. Therefore, stopping the overexpression of ARs, the miR-125b will be inhibited and cardiac inflammation and fibrosis would be treated. This particularly encouraged treatment with degradation enhancer of AR that limits cardiac fibrosis in iDCM, thereby providing potentially a therapeutic approach for patients with iDCM.(36)

Moreover, after identifying a novel microRNA in mice and humans with myocarditis, they found that the human homologue (hsa-miR-Chr8:96) could be used to distinguish patients with myocarditis from those with myocardial infarction. This was identified after inducing autoimmune myocarditis in mice which produced interleukin 17(from TH17 cells) a characteristic feature of myocardial injury in the acute phase of myocarditis. The microRNA mmu-miR-721 was synthesized by Th17 cells and was present in the plasma of mice with acute autoimmune or viral myocarditis but not in those with acute myocardial infarction ${ }^{11}$. Another example is the role of the miR-221/-222 family that shows that microRNA-221 (miR-221) and miR-222 levels are significantly elevated during acute VM caused by Coxsackievirus B3 (CVB3). That is upregulated in VM. The miR-221/-222 cluster was found to have antiviral and inflammatory immune responses to viral infection of the heart. Its inhibition increases viral load, inflammation, and overall cardiac injury upon VM(40).

Exosomes are membrane-bound extracellular vesicles involved in cell signalling ${ }^{9}$. A study by Fan et al, examined the expression of 10 candidate miRNAs in the serum exosome by qRT-PCR in 23 patients with Coxsackievirus B3 (CVB3) viral myocarditis (VM) and 12 controls. Among them, miR-1, -27b, -148a and -133a are heart-associated; miR-146b, 30a, -155, -181d and -125a are immune-associated; miR-21 is fibrosis associated. The study described 5 miRNAs with disturbed expression in CVB3 VM patients which may be potentially used as biomarkers for VM diagnosis. Not only were they found in serum exosomes, but also, two of these miRNAs were found to have altered expression in cells after CVB3 infection. The miRNAs miR-30a and -181d were significantly up-regulated after CVB3 infection. The study further identified suppressor of cytokine signaling-3 (SOCS3) as a target for miR-30a and -181d, as predicted by bioinformatics tools and confirmed by dual luciferase assay and Western blot. In addition to this, up-regulated miR-30a and -181d are responsible for the elevated IL-6 levels via modulating SOCS3 expression during CVB3 infection. Furthermore, miRNA inhibitors injection increased mice survival rate after CVB3 infection. Findings of this study suggest that miR-30a and -181d are responsible for the over-activated inflammatory response to CVB3 viral infection of the heart(41) 
The development of newer modes of treatment of myocarditis was also suggested by a study where RT-qPCR showed miR-141-3p expression to be reduced in mice with experimental autoimmune myocarditis (EAM). In order to test its effect on the pathology of EAM, a group of mice were injected with miR-141-3p agomir. The results showed reduced LVEDd and LVEDs on echocardiography in the non-injected mice while LVEF and LVFS in miR-141-3p agomir injected mice were increased proving its protective effect. Existing literature has proven miRNAs to be involved in mediation of immune inflammation in cardiac diseases ${ }^{31}$. Overexpression of miR-141$3 p$ was found to decrease myocardial inflammation through suppressing STAT4. In this study, the results showed a decrease in miR-141-3p levels with increased STAT4 levels, suggesting that STAT4 is a target gene for miR-141-3p.(42)

Lastly, through experimentation on mice it is found that miRNA-98 showed suppression of IL-10 (a strong mediator from B-cells) causing protection and limitation of the severity of myocarditis which may be a new gate for targeted therapy for myocarditis. We can therefore conclude that microRNAs can be used as a diagnostic and therapeutic tool as medicine advances.(43)

\section{B)Viral miRNAs interact with host genome, a new miRNA mediated interplay between host and viruses.}

\section{1-As mentioned earlier, discovery of viral miRNAs has become a point of focus in the last 10 years. Two different approaches have been used to identify v-miRNAs:(44)}

a- The use of computational tools to predict the secondary structure of the precursor of v-miRNAs (pre-vmiRNAs). This approach usually results in a large number of false positives, however, it can lead to the identification of less abundant miRNA.

b-Sequencing of cloned small RNA molecules; however, less abundant miRNA may be left out.

2-Notably, more than $250 v$-miRNAs have been identified, and the majority of them are accounted for in the DNA viruses of the herpesvirus family. Studies have indicated that viruses utilize the cellular machinery to encode miRNA. The detection of v-miRNAs in RNA viruses has been controversial, with a few reports suggesting noncanonical miRNA-like small RNAs produced during RNA virus infections; however, these small RNAs lack the canonical stem-loop structure found in miRNAs, so their biogenesis and function are not well-understood. (45)

The following reasons might explain the lack of v-miRNAs produced by RNA viruses during infection; a- the RNA viruses consists either +/- sense or double-stranded RNA (dsRNA) and replicate in the cytoplasm of the host cell, so the RNA molecules are not accessible to the miRNA biogenesis machinery in the nuclei; b-excision of premiRNA from the primary transcript might result in the destruction of RNA-based viral genomes; $c$-the generated v-miRNA may target the viral genome itself, resulting in cleavage of the viral genome.

\section{3-Functions of viral miRNAs include the following;(46)}


a-Improve cell survival:

A classic example is EBV miR-BART5, which controlled proliferation and established latent infection by targeting PUMA. PUMA is known to modulate apoptosis by $\mathrm{p} 53$, so by suppressing PUMA, EBV miRNAs alter the susceptibility to apoptotic agents and improve host cell survival.

b-Alter cytokine expression:

KSHV v-miRNAs reduce expression of C/EBPß p20 (LIP), a known negative regulator of IL6 and IL10 cytokines, to regulate the cytokine signaling in infected cells. This leads to overexpression of pro-inflammatory IL-6 leading to tissue damage.

c-Alter antiviral immune responses:

HCMV miRNAs have been shown to target host genes involved in the antiviral immune response. miR-UL112 blocks the natural killer (NK) cell-mediated recognition of virus-infected cells by inhibiting the expression of MICB, a stress-induced ligand essential for NK-cell activity.(46)

Table 2 summarizes the number of miRNAs released by different DNA and RNA viruses.

\section{C)Why myocarditis from mRNA vaccines seems to decrease with age.}

From table 1 we can conclude that most of the cases of myocarditis from mRNA vaccines occurs in individuals aged 50 years or below. Key miRNA involved in induction of myocarditis are expressed in skeletal muscles, an interesting example is miRNA 155, sarcopenia or loss of muscle mass is most pronounced after the age of 50 years, occurring steadily at a rate of 1 to $2 \%$ annually. This loss of muscle mass has been correlated to levels of micro RNAs, specifically microRNA 155, with aging, by Ong and colleagues. They found that miRNA 155 decreases with age. This perfectly matches our hypothesis and might also help in stratifying individuals at higher risk of myocarditis from mRNA vaccines by the sarcopenia index, the higher the index is, the lower the risk of myocarditis from mRNA vaccines. This also could also explain the predominance of male gender in the observed complication, having a higher muscle mass compared to females. (47)

\section{D)Diagnostic and therapeutic implications:}

\section{1-Predicting mRNA-vaccines related myocarditis.}

It is clear from the above that viral RNA can either alter the expression of host miRNA or use cellular machinery to form viral miRNAs. Farr, Rohani, Fani and others have used next generation sequencing to determine microRNAs implicated in severe COVID-19. Interestingly, we found that many of the miRNAs implicated in severe COVID-19, have been identified as potential targets for viral myocarditis as mentioned earlier (Table3). We summarized in Table 3 those miRNAs. The screening of the presence of such miRNAs can therefore be used to determine the likelihood of recipients of mRNA vaccines in developing myocarditis. This needs more studies regarding cost-effectiveness given the relative rarity of the complication. (48-50) 


\section{2-Therapeutic targets:}

MicroRNAs (miRNA) have recently become attractive targets for therapeutic intervention. The rationale for developing miRNA therapeutics is based on the premise that aberrantly expressed miRNAs play key roles in the development of human disease, and that correcting these miRNA deficiencies by either antagonizing or restoring miRNA function may provide a therapeutic benefit. Myocarditis, and advanced or end-stage heart failure, poses significant challenge as all the available medications, including the newest sacubitril-valsartan or ivabradine, do not abolish the need for cardiac transplantation. Cardiac transplantation is a difficult procedure and is not always an available option due to long waiting times on transplant lists, and lack of standardized policy regarding brain0stem dead donors. Therefore, those conditions have become among the first where clinical trials of miRNAs therapeutics have been implemented.

\section{a-Direct use of miRNAs}

The microRNA-132-3p (miR-132) is a regulatory (noncoding) RNA that, in response to cardiomyocyte stress, is upregulated in cardiac tissue. It affects signaling pathways involved in cardiomyocyte growth, autophagy, calcium handling, and contractility. Thus, miR-132 appears as a potentially promising molecular pathophysiological target in HF treatment. CDR132L, a synthetic locked nucleic acid antisense oligonucleotide (ASO) inhibitor with a fully phosphorylated backbone, is a first-in-class miR-132 inhibitor.

A prospective, randomized, double-blind, placebo-controlled, dose-ranging study of intravenous CDR132L was performed by Täubel and colleagues on twenty-eight HF patients, with left ventricular ejection fraction between $\geq 30 \%$ and $<50 \%$ or amino terminal fragment of pro-brain natriuretic peptide (NT-proBNP) $>125 \mathrm{ng} / \mathrm{L}$ at screening, were randomized to receive $\operatorname{CDR} 132 \mathrm{~L}(0.32,1,3$, and $10 \mathrm{mg} / \mathrm{kg}$ body weight) or placebo ( $0.9 \%$ saline) . CDR132L treatment resulted in a dose-dependent, sustained miR-132 reduction in plasma. Patients given CDR132L $\geq 1 \mathrm{mg} / \mathrm{kg}$ displayed a median $23.3 \%$ NT-proBNP reduction, vs. a $0.9 \%$ median increase in the control group. CDR132L treatment induced significant QRS narrowing and encouraging positive trends for relevant cardiac fibrosis biomarkers.CDR132L was safe and well tolerated, without apparent dose-limiting toxicity. A pharmacokinetic/pharmacodynamic dose modelling approach suggested an effective dose level at $1 \mathrm{mg} / \mathrm{kg}$ CDR132L.

It was found that not only the direct inhibition of a miRNA was proven useful, but that indirect inhibition can do wonders as well. (51)

b-Indirect modulation of miRNAs

*One method of indirect inhibition of a miRNA included tackling a viral RNA helicase, responsible for miRNA expression. This has shown some encouraging results and has allowed us to ask a question; how can we correlate this discovery with the ongoing pandemic?

SARS COV2 is a single stranded RNA virus, and it has been recently established to cause myocarditis along with other cardiac morbidities, such as pericarditis and pericardial effusion. This is due to the highly ACE-2expressive cardiomyocytes, with which the virus interacts, facilitating its entry. 
Similarly, Coxsackievirus B3 is a single stranded RNA virus, which modern science has failed to find a vaccine against thanks to its everchanging surface capsid proteins allowing it to always escape the proper immune response.

To overcome this limitation, Soo-Hyeon Yun et al decided to investigate other CVB3 antiviral treatment options that tackle the virus throughout its life cycle such as a chemically modified enterovirus-2C inhibitor (E2Cl). E2C is a viral RNA helicase that normally limits host protein synthesis. Accordingly, by inhibiting the E2C, a better chance is given to overcome virally induced cardiac morbidity. Soo-Hyeon Yun et al held a murine viral myocarditis model where CVB3 infected mice with \& without E2Cl were carefully studied. The 4-week survival rate of $\mathrm{E} 2 \mathrm{Cl}$ injected mice was significantly higher than their non-injected counterparts. Viral titers, myocardial inflammation, remodeling-induced cardiomyopathy all significantly dropped in treated mice.(52)

Comparably, Marie Pierre Lambert et al explored a similar correlation between certain RNA helicases and proneural microRNAs in mice, and how this intricate interplay can affect neurogenesis or lack of. According to the aforementioned paper, DDX17 \& DDX5 are both ATP-dependent RNA helicases that virtually regulate most steps of gene expression, cell fate switches, biological transition and nuclear maturation of some miRNAs' precursors through interaction with their microprocessor components. REST factor suppresses a number of neuronal genes in non-neuronal cells \& is especially regulated by said helicases. MiR-26a is the main DXX17/DXX5 dependent neuronal miRNA present in mammals expressed from 2 different genetic loci that generate 2 precursors: primir26a1 andf pri-mir26a2, where the miR-26a's main pool comes from the latter. It was found that, in the presence of DDX17, processing and cleavage of pri-mir26a2 were enhanced, resulting in lack of neurogenesis. On the other hand, silencing of DDX17 results in an accumulation of pri-mir26a2 due to its lack of proper processing and cleavage, which in return promotes neurogenesis. In addition to that, accumulated pri-mir26a2 exerted negative feedback on DDX17, which in exchange decreased REST factor's binding to its target promotors favoring further neurogenesis.

Taking the previous two models into consideration, we hypothesize that if we can conduct an inhibitory approach concerning SARS-COV2 viral helicases, we might be able to similarly upregulate certain beneficial myocardial miRNA which will promote reversed myocardial remodeling when it comes to virally induced myocarditis. (53)

REST=Repressor Element 1-silencing transcription

*Another promising method of indirect inhibition of a miRNA was displayed in the following drug's mechanism of action.

Pirfenidone, an oral, small molecule, anti-fibrotic agent that acts by inhibiting the activation of cardiac fibroblasts, and inhibiting the production of peptides, such as transforming growth factor- $\beta$. It also works by antisense oligonucleotides directed against cardiotropic long non coding RNA (miRNA, IncRNA), silencing miRNA -21 that promotes cardiac fibrosis, therefore it manages to diminish fibroblast proliferation and collagen type 1 production and crosslinking that causes heart fibrosis. 
It is used in idiopathic pulmonary fibrosis.

In a randomized clinical trial conducted by Gavin A Lewis et al, to evaluate the efficacy of Pirfenidone in treatment of Heart Failure patients with preserved ejection fraction, Pirfenidone and Placebo were compared in the treatment of HFpEF in 47 participants of a mean age 78 years and mean myocardial Extracellular Volume $30 \%$, shown by cardiac imaging $30 \%$.

Results showed great reduction in ECV containing collagen and water from baseline in 52 weeks, where 100 capsules of pirfenidone that were taken (11days $\mathrm{ttt} t$ target dose) resulted in mean ECV reduction at 52 weeks of $0.06 \%$, with improvement in 8 out if $10 \mathrm{KCCQ}$ score, including clinical improvements and log NT-proBNP reduction.

The reduction in log NT-proBNP with pirfenidone was suggested to be due to an improvement in left ventricular myocardial stiffness secondary to myocardial fibrosis regression.

The outcome of decrease in ECV in association with log NT-proBNP reduction, provides further support for its effect in decreasing heart fibrosis and thus the effectiveness of the drug in treatment of HFpEF, possibly through non-coding miRNA silencing. The drug is effective in the structural wise changes but not the hemodynamic changes occurring in Heart failure. So, RAAS inhibitors should be studied for cardiac hemodynamic effect, synergistically with pirfenidone.

Figure 4 summarizes the implications tackled in the article

\section{Conclusion}

We can conclude from the above that, miRNA upregulation or downregulation by mRNA vaccines might explain the myocarditis observed from such vaccines. This hypothesis explains why younger individuals are at higher risk of myocarditis, having a larger muscle mass with upregulation of key miRNA such as miRNA 155 being highly expressed in skeletal muscles. Recognition of this might lead to tailoring of multiple tools for risk stratification of this complication before receiving mRNA vaccines, such as sarcopenia index or testing for some key miRNAs (such as miRNA155). It can also have therapeutic tools by developing anti-sense miRNAs blocking the action of the implicated miRNAs and thus preventing the myocarditis process.

\section{List Of Abbreviations}




\begin{tabular}{|c|c|}
\hline AMOs & Anti-miRNAs Oligonucleotides \\
\hline Ang 2 & Angiotensin 2 \\
\hline AR & Androgen Receptor \\
\hline ASO & Anti-sense Oligonucleotide \\
\hline $\mathrm{Bcl}-2$ & B-cell Lymphoma 2 \\
\hline $\mathrm{Bcl}-\mathrm{xl}$ & B-cell Lymphoma extra large \\
\hline CMV & Cytomegalovirus \\
\hline COVID-19 & Corona Virus Disease-2019 \\
\hline CVB3 & Coxackie Virus B3 \\
\hline DCM & Idiopathic Dilated Cardiomyopathy \\
\hline $\mathrm{E} 2 \mathrm{Cl}$ & Enterovirus-2C inhibitor \\
\hline EBV & Epstein Barr Virus \\
\hline ECM & Extracellular Matrix \\
\hline ECV & Extracellular Volume \\
\hline FDA & Food and Drug Administration \\
\hline $\mathrm{HF}$ & Heart Failure \\
\hline HIT & Heparin-induced Thrombocytopenia \\
\hline IFN & Interferon \\
\hline IL & Interleukin \\
\hline KSHV & Kaposi Sarcoma-like Herpes Virus \\
\hline LNA & Locked Nucleic Acid \\
\hline LVED & Left Ventricular End Diastolic \\
\hline LVEF & Left Ventricular Ejection Fraction \\
\hline LVFS & Left Ventricular Fractional Shortening \\
\hline MICB & Micro-invasive Carcinoma of Breast \\
\hline MiRNA & Micro RNA \\
\hline MRNA & Messenger RNA \\
\hline NK & Natural Killer \\
\hline NT-proBNP & Amino Terminal Fragment of pro Brain Natriuretic Peptide \\
\hline PCR & Polymerase Chain Reaction \\
\hline PDCD4 & Programmed Cell Death 4 \\
\hline
\end{tabular}

Page $12 / 24$ 


\begin{tabular}{|ll|}
\hline RAAS & Renin Angiotensin Aldosterone System \\
\hline REST & Repressor Element 1 Silencing Transcription \\
\hline SOCS-3 & Severe Acute Respiratory Syndrome \\
\hline TNF & Tumpressor of Cytokine Signaling3 \\
\hline TUG & Taurine Up-regulated Gene \\
VMC & Viral Myocarditis \\
\hline
\end{tabular}

\section{Tables}




\begin{tabular}{|c|c|c|c|c|c|c|c|}
\hline \multicolumn{7}{|c|}{ Table 1: Reported myocarditis cases from mRNA vaccines } & \multirow[b]{2}{*}{ Remarks } \\
\hline $\begin{array}{l}\text { Reference } \\
\text { number in } \\
\text { the text and } \\
\text { authors }\end{array}$ & $\begin{array}{l}\text { Number } \\
\text { of cases }\end{array}$ & Age Range & Sex & $\begin{array}{c}\text { Type of } \\
\text { involved } \\
\text { vaccine }\end{array}$ & $\begin{array}{c}\text { Vaccine } \\
\text { dose after } \\
\text { which } \\
\text { myocarditis } \\
\text { developed }\end{array}$ & $\begin{array}{c}\text { Median } \\
\text { time of } \\
\text { onset of } \\
\text { myocarditis } \\
\text { after } \\
\text { vaccination } \\
\text { (in hours) }\end{array}$ & \\
\hline $\begin{array}{c}5 \text { Singh et } \\
\text { al }\end{array}$ & 1 & 24 & $\mathrm{M}$ & $\begin{array}{l}\text { Pfizer- } \\
\text { BioN }\end{array}$ & 2nd & 72 & \\
\hline $\begin{array}{c}6 \text { Hudson et } \\
\text { al }\end{array}$ & 2 & $22 \& 24$ & $\bar{M}$ & $\begin{array}{l}\text { Pfizer- } \\
\text { BioN }\end{array}$ & 2nd & 72 & \\
\hline $\begin{array}{c}7 \text { William et } \\
\text { al }\end{array}$ & 1 & 34 & $\mathrm{M}$ & Moderna & 2nd & 72 & \\
\hline 8 Tailor & 1 & 44 & $\mathrm{M}$ & Moderna & 2nd & 120 & \\
\hline $\begin{array}{c}9 \text { Acharya et } \\
\text { al }\end{array}$ & 1 & 18 & $\bar{M}$ & $\begin{array}{l}\text { Pfizer- } \\
\text { BioN } \\
\text { Tech }\end{array}$ & 2nd & 72 & \\
\hline 10 Dickey & 6 & $\begin{array}{c}17-37 \\
(100 \%<50 \\
y \text { age })\end{array}$ & $\mathrm{M}$ & $\begin{array}{l}\text { Pfizer- } \\
\text { BioN } \\
\text { Tech \& } \\
\text { Moderna }\end{array}$ & 2nd & 72 & \\
\hline $\begin{array}{c}11 \text { Vidula et } \\
\text { al }\end{array}$ & 2 & $18-19$ & $\begin{array}{l}2 \mathrm{M} \\
\& \\
3 \mathrm{~F}\end{array}$ & $\begin{array}{l}\text { Pfizer- } \\
\text { BioN } \\
\text { Tech \& } \\
\text { Moderna }\end{array}$ & 2nd & "50" & $\begin{array}{l}\text { The series } \\
\text { included } 5 \\
\text { cases, } \\
\text { among } \\
\text { which only } \\
\text { two were } \\
\text { having } \\
\text { myocarditis }\end{array}$ \\
\hline $\begin{array}{c}12 \\
\text { Patrignani et } \\
\text { al }\end{array}$ & 1 & 56 & $\bar{M}$ & $\begin{array}{l}\text { Pfizer- } \\
\text { BioN } \\
\text { Tech }\end{array}$ & 1 st & 4 & $\begin{array}{l}\text { History of } \\
\text { COVID-19 } \\
\text { infection }\end{array}$ \\
\hline 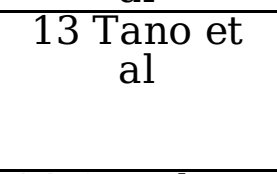 & 1 & 29 & $\mathrm{M}$ & Moderna & 1st & 6 & $\begin{array}{l}\text { History of } \\
\text { myocarditis } \\
8 \text { years } \\
\text { before }\end{array}$ \\
\hline 14 Cereda et & 1 & 21 & $\mathrm{M}$ & $\begin{array}{l}\text { Pfizer- } \\
\text { BioN }\end{array}$ & 2nd & 2 & \\
\hline$\underset{\mathrm{al}}{15 \mathrm{Kim} \text { IC et }}$ & 1 & 24 & $\bar{M}$ & $\begin{array}{l}\text { Pfizer- } \\
\text { BioN } \\
\text { Tech }\end{array}$ & 2nd & 24 & \\
\hline $\begin{array}{c}16 \text { Ryan , } \\
\text { Montgomery } \\
\text { et al }\end{array}$ & 23 & $\begin{array}{c}20-51 \\
\text { (Exact age } \\
\text { distribution } \\
\text { not } \\
\text { reported } \\
\text { among } \\
\text { cases) }\end{array}$ & $\mathrm{M}$ & $\begin{array}{c}7 \\
\text { received } \\
\text { Pfizer- } \\
\text { BioN } \\
\text { Tech \& } \\
16 \\
\text { received } \\
\text { Moderna }\end{array}$ & $\begin{array}{l}2^{\text {nd }} \text { in all } \\
\text { but } 3 \text { cases }\end{array}$ & 50 & $\begin{array}{l}\text { The three } \\
\text { cases } \\
\text { developing } \\
\text { myocarditis } \\
\text { from } \\
\text { firstdose } \\
\text { had } \\
\text { previous } \\
\text { COVID-19 } \\
\text { infection }\end{array}$ \\
\hline$\underset{\text { et al }}{17 \text { Kim HW }}$ & 4 & $\begin{array}{c}23-70 \text { (75\% } \\
<50 \text { y age, } \\
25 \%>50 \text { y } \\
\text { age) }\end{array}$ & $\begin{array}{l}3 \mathrm{M} \\
1 \mathrm{~F}\end{array}$ & $\begin{array}{c}2 \\
\text { received } \\
\text { Pfizer-- } \\
\text { BioN 2 } \\
\text { Received } \\
\text { Moderna }\end{array}$ & 2nd & "50" & \\
\hline $\begin{array}{c}18 \\
\text { Muthukumar } \\
\text { et al }\end{array}$ & 1 & 52 & $\bar{M}$ & Moderna & 2nd & 72 & \\
\hline $\begin{array}{c}19 \mathrm{Abu} \\
\text { Mouch et al }\end{array}$ & 6 & $\begin{array}{c}16-45 \\
(100 \%<50\end{array}$ & $\overline{\mathrm{M}}$ & $\begin{array}{l}\text { Pfizer- } \\
\text { BioN }\end{array}$ & $2^{\text {nd }}$ in 5 & "48" & $\begin{array}{l}\text { The only } \\
\text { patient }\end{array}$ \\
\hline
\end{tabular}




\begin{tabular}{|c|c|c|c|c|c|c|c|}
\hline & & y age) & & Tech & and $1^{\text {st }}$ in 1 & & $\begin{array}{l}\text { developing } \\
\text { myocarditis } \\
\text { in this } \\
\text { series after } \\
\text { first dose, } \\
\text { developed it } \\
\text { after } 16 \\
\text { days of this } \\
\text { dose }\end{array}$ \\
\hline $\begin{array}{c}20 \text { Larson et } \\
\text { al }\end{array}$ & 8 & $\begin{array}{c}21-56 \\
(87.5 \% \\
<50 y \mathrm{age} \\
12.5 \%>50 \\
\text { y age })\end{array}$ & $\mathrm{M}$ & $\begin{array}{c}5 \\
\text { received } \\
\text { Pfizer } \\
\text { and } 3 \\
\text { received } \\
\text { Moderna }\end{array}$ & $\begin{array}{l}2^{\text {nd }} \text { in all } \\
\text { but one }\end{array}$ & "72" & $\begin{array}{l}\text { The only } \\
\text { patient } \\
\text { developing } \\
\text { myocarditis } \\
\text { in this } \\
\text { series after } \\
\text { first dose, } \\
\text { had } \\
\text { previous } \\
\text { COVID-19 } \\
\text { infection }\end{array}$ \\
\hline $\begin{array}{l}21 \text { Marshall } \\
\text { et al }\end{array}$ & 7 & $\begin{array}{c}14-19 \\
(100 \%<50 \\
\text { v aqe) }\end{array}$ & $\mathrm{M}$ & $\begin{array}{l}\text { Pfizer- } \\
\text { BioN }\end{array}$ & 2nd & "72" & \\
\hline $\begin{array}{c}22 \text { Albert et } \\
\text { al }\end{array}$ & 1 & 24 & $\mathrm{M}$ & Moderna & 2nd & 96 & \\
\hline $\begin{array}{l}23 \text { Bautista } \\
\text { et al }\end{array}$ & 1 & 39 & $\mathrm{M}$ & $\begin{array}{l}\text { Pfizer- } \\
\text { BioN }\end{array}$ & 2nd & 144 & \\
\hline $\begin{array}{c}24 \text { Rosner et } \\
\text { al }\end{array}$ & 7 & $19-39$ & $\bar{M}$ & $\begin{array}{l}\text { Pfizer- } \\
\text { BioN }\end{array}$ & $\begin{array}{l}\text { 2nd except } \\
\text { in } 1 \text { case }\end{array}$ & 72 & $\begin{array}{l}\text { The only } \\
\text { patient } \\
\text { developing } \\
\text { myocarditis } \\
\text { in this } \\
\text { series after } \\
\text { first dose, } \\
\text { developed it } \\
\text { after } 7 \text { days } \\
\text { of this dose }\end{array}$ \\
\hline $25 \underset{\text { et al }}{\text { Ammirati }}$ & 1 & 56 & $\mathrm{M}$ & $\begin{array}{l}\text { Pfizer- } \\
\text { BioN }\end{array}$ & 2nd & 72 & \\
\hline $\begin{array}{l}26 \text { McLean } \\
\text { et al }\end{array}$ & 1 & 16 & $\bar{M}$ & $\begin{array}{l}\text { Pfizer- } \\
\text { BioN }\end{array}$ & 2nd & 60 & \\
\hline $\begin{array}{l}27 \text { D'Angelo } \\
\text { et al }\end{array}$ & 1 & 30 & $\mathrm{M}$ & $\begin{array}{l}\text { Pfizer- } \\
\text { BioN }\end{array}$ & 2nd & 72 & \\
\hline $\begin{array}{c}28 \text { Snapiriet } \\
\text { al }\end{array}$ & 7 & $16-18$ & $\mathrm{M}$ & $\begin{array}{l}\text { Pfizer- } \\
\text { BioN }\end{array}$ & $\begin{array}{l}\text { 2nd except } \\
\text { in } 1 \text { case }\end{array}$ & 48 & $\begin{array}{l}\text { The case } \\
\text { developing } \\
\text { myocarditis } \\
\text { after 1st } \\
\text { dose had } \\
\text { positive } \\
\text { COVID19 } \\
\text { serology }\end{array}$ \\
\hline $\begin{array}{l}29 \text { Mansour } \\
\text { et al }\end{array}$ & 2 & 25 & $\mathrm{M}$ & Moderna & 2nd & 27 & \\
\hline $\begin{array}{l}30 \text { Minocha } \\
\text { et al }\end{array}$ & 1 & 21 & $\mathrm{~F}$ & $\begin{array}{l}\text { Pfizer- } \\
\text { BioN }\end{array}$ & 2nd & 48 & $\begin{array}{l}\text { Previous } \\
\text { history of } \\
\text { myocarditis } \\
8 \text { month } \\
\text { ago }\end{array}$ \\
\hline
\end{tabular}

Table 2: DNA and RNA viruses producing miRNAs, the numbers of miRNAs discovered for each 


\begin{tabular}{|l|l|l|}
\hline Virus Family & Type & Number of encoded pre-miRNAs and miRNAs \\
\hline$\gamma$-Herpesvirus & DNA & 40 pre-miRNAs and 4 mature miRNAs \\
\hline$\beta$-Herpesvirus & DNA & 26 miRNAs related mainly to HCMV \\
\hline$\alpha$-Herpesvirus & DNA & 24 functional miRNAs \\
\hline Papillomavirus & DNA & Four (two by HPV16, one by HPV38, and one by HPV68) \\
\hline Hepadnavirus & DNA & only one \\
\hline Adenovirus & DNA & encodes two miRNAs \\
\hline Polyomavirus & DNA & one pre-miRNA at the $3^{\prime}$ end that encodes two mature miRNAs \\
\hline Influenza Virus & RNA & encodes small viral leader miRNAs \\
\hline Ebola Virus & RNA & seven mature miRNAs from four pre-miRNAs \\
\hline HIV-1 & RNA & five putative pre-miRNAs \\
\hline
\end{tabular}

Abbreviations: DNA: Deoxy-Ribonucleic acid, HCMV: Human Cytomegalovirus, HIV: Human immunodeficiency virus, HPV: Human Papilloma Virus, miRNA: Micro Ribonucleic acid.

Table 3: Host miRNA profiles shared in viral myocarditis as well as severe COVID-19 (References in text:41, 49,50) 


\begin{tabular}{|c|c|}
\hline & unctions \\
\hline $\begin{array}{l}-5 p \\
\text { ip and } \\
-3 p\end{array}$ & $\begin{array}{l}\text { They are expressed on immune cells and play a role in both innate immunity } \\
\text { and myocardial infarction. They regulate the synthesis and release of pro- } \\
\text { inflammatory cytokines in the heart through Toll-like (TRL) receptors and } \\
\text { their downstream signaling cascade, which includes the transcription nuclear } \\
\text { factor-kappa B (NF-kB). The three were among the most deregulated miRNAs } \\
\text { upon SARS-CoV infection. }\end{array}$ \\
\hline$-5 p$ & e COVID-19 infe \\
\hline ated & $\begin{array}{l}\text { One of the miRNAs that are persistently modulated in both human and mouse } \\
\text { viral myocarditis. It attributes to myocardial damage by modulating } \\
\text { monocyte-macrophage cardiac infiltration and T lymphocyte activation. It is } \\
\text { expressed in immune cells and involved in both innate immune response and } \\
\text { myocardial infarction or HF. Toll-like (TRL) receptors and their downstream } \\
\text { signaling cascade, involving the transcription nuclear factor-kappa B (NF- } \\
\text { KB), control the synthesis and secretion of pro-inflammatory cytokines in the } \\
\text { heart. }\end{array}$ \\
\hline ated & $\begin{array}{l}\text { It inhibits the release of anti-inflammatory cytokines and triggers the release } \\
\text { of pro-inflammatory cytokines by targeting PDCD } 4 \text { (Programmed Cell Death } \\
\text { 4), one of the components of the NF-k B pathway. Initially, high levels were } \\
\text { linked to serious disease. However, upon further classification into low and } \\
\text { high miR concentrations divided by the median concentration, Lower miR-21 } \\
\text { levels were associated with more ventilation and vasopressor days, as well as } \\
\text { a greater rate of extracorporeal membrane oxygenation (ECMO) and renal } \\
\text { replacement therapy. }\end{array}$ \\
\hline & possible association, further research is necessary due to inconsistent \\
\hline & $\begin{array}{l}\text { It's expressed on immune cells and plays a role in both innate immunity and } \\
\text { myocardial infarction. It regulates the synthesis and release of pro- } \\
\text { inflammatory cytokines in the heart through Toll-like (TRL) receptors and } \\
\text { their downstream signaling cascade, which includes the transcription nuclear } \\
\text { factor-kappa B (NF-kB). }\end{array}$ \\
\hline$-3 p$ & $\begin{array}{l}\text { on, } \\
\text { s a } \\
\text { rels }\end{array}$ \\
\hline & \\
\hline $\begin{array}{l}-5 p, \\
\text { with } \\
a-5 p\end{array}$ & $\begin{array}{l}\text { ry response } \\
\text { ttwork. The } \\
\text { tion, which } \\
\text { ctivation. }\end{array}$ \\
\hline ated & $\begin{array}{l}\text { MiR-146a-5p transcription is enhanced as the inflammatory response } \\
\text { progresses, blocking its targets IRAK1 and TRAF6, and decreasing NF-KB } \\
\text { activation. }\end{array}$ \\
\hline $\begin{array}{l}-3 \mathrm{p} \\
\text { iR-4 }\end{array}$ & $\begin{array}{l}\text { ed in the plasma of individuals with viral } \\
\text { s were found to correlate with myocardial } \\
\mathrm{n} \text { T levels. }\end{array}$ \\
\hline ate & $\begin{array}{l}\text { They were significantly up-regulated in COVID-19 patients, inducing } \\
\text { myocardial damage. Increased levels were linked to elevated procalcitonin } \\
\text { and lactate levels. In COVID-19 survivors, upregulation of miR-21, miR155, } \\
\text { miR-208a, and miR-499 could be a predictor of chronic myocardial injury and } \\
\text { inflammation. Despite, the fact that troponin levels were higher in the }\end{array}$ \\
\hline
\end{tabular}


Influenza-ARDS group, COVID-19 had higher levels of cardiac specific miR208a and miR-499.

b, miR- It has been discovered to target ACE2, and in vitro investigations have shown d miR- that miR-200c regulation regulates ACE2 expression.

It is involved in CVDs and is upregulated by oxidative stress. This indicates that miR200c-mediated regulation of ACE2 may be essential for SARS-COV-2

ated entry.

$\mathrm{a}$

It is associated with macrophage infiltration, cardiac injury, enhanced LV function, and clinical prognosis.

yulated

Abbreviations:

ACE: Angiotensin Converting Enzyme, COVID-19: Coronavirus disease 2019, CVD:

Cardiovascular disease, IL-1R-associated kinase 1: IRAK, LV: Left Ventricle, miR: Micro-

Ribonucleic acid, NF: Nuclear Factor, PD: Programmed death, SARS-CoV: severe acute respiratory syndrome coronaviridae, TLR: Toll like receptor.

\section{References}

1. Krause PR, Gruber MF. Emergency Use Authorization of Covid Vaccines - Safety and Efficacy Follow-up Considerations. New England Journal of Medicine. 2020 Nov 5;383(19).

2. AbdelMassih A, Hozaien R, el Shershaby M, Kamel A, Ismail H-A, Fouda R. Is the heparin-induced thrombocytopenia-like syndrome associated with ChAdOx vaccine related to the vaccine itself or to an autoimmune reaction to severe acute respiratory syndrome 2 coronavirus: insights and implications from previous reports in infected cases? New Microbes and New Infections. 2021 May;41.

3. Simone A, Herald J, Chen A, Gulati N, Shen AY-J, Lewin B, et al. Acute Myocarditis Following COVID-19 mRNA Vaccination in Adults Aged 18 Years or Older. JAMA Internal Medicine. 2021 Oct 4;

4. Bozkurt B, Kamat I, Hotez PJ. Myocarditis With COVID-19 mRNA Vaccines. Circulation. 2021 Aug 10;144(6).

5. Singh B, Kaur P, Cedeno L, Brahimi T, Patel P, Virk H, et al. COVID-19 mRNA Vaccine and Myocarditis.

European Journal of Case Reports in Internal Medicine. 2021 Jun 14;

6. Hudson B, Mantooth R, DeLaney M. Myocarditis and pericarditis after vaccination for COVID-19. Journal of the American College of Emergency Physicians Open. 2021 Aug 26;2(4).

7. Williams CB, Choi J, Hosseini F, Roberts J, Ramanathan K, Ong K. Acute Myocarditis Following mRNA-1273 SARS-CoV-2 Vaccination. CJC Open. 2021 Jul;

8. Tailor PD, Feighery AM, El-Sabawi B, Prasad A. Case report: acute myocarditis following the second dose of mRNA-1273 SARS-CoV-2 vaccine. European Heart Journal - Case Reports. 2021 Aug 1;5(8). 
9. Acharya S, Brand M, Lee J, Macqueen D, Arbach A, Bhattarai S. COVID-19 mRNA Vaccine Induced Troponinemia - Is the Vaccine a Cardiac Stressor? International Journal of Clinical Cardiology Open Access Citation. 2021;8:232.

10. Dickey JB, Albert E, Badr M, Laraja KM, Sena LM, Gerson DS, et al. A Series of Patients With Myocarditis Following SARS-CoV-2 Vaccination With mRNA-1279 and BNT162b2. JACC: Cardiovascular Imaging. 2021 Sep;14(9).

11. Vidula MK, Ambrose M, Glassberg H, Chokshi N, Chen T, Ferrari VA, et al. Myocarditis and Other Cardiovascular Complications of the mRNA-Based COVID-19 Vaccines. Cureus. 2021 Jun 10;

12. Patrignani A, Schicchi N, Calcagnoli F, Falchetti E, Ciampani N, Argalia G, et al. Acute myocarditis following Comirnaty vaccination in a healthy man with previous SARS-CoV-2 infection. Radiology Case Reports. 2021 Nov;16(11).

13. Giuseppe Di Tano LMEVC and GBD. Recurrent Myocarditis after the First Dose of SARS-CoV-2 mRNA-1273 Vaccine [Internet]. 2021. Available from: http://anncaserep.com/

14. Cereda A, Conca C, Barbieri L, Ferrante G, Tumminello G, Lucreziotti S, et al. Acute myocarditis after the second dose of SARS-CoV-2 vaccine: Serendipity or atypical causal relationship? Anatolian Journal of Cardiology. 2021 Jul 1;25(7):522-3.

15. Kim I-C, Kim H, Lee HJ, Kim JY, Kim J-Y. Cardiac Imaging of Acute Myocarditis Following COVID-19 mRNA Vaccination. Journal of Korean Medical Science. 2021;36(32).

16. Ryan M, Montgomery J, Engler R, Hoffman D, McClenathan B, Collins L, et al. Myocarditis following immunization with mrna covid-19 vaccines in members of the us military. JAMA Cardiology. 2021 Oct $1 ; 6(10): 1202-6$.

17. Kim HW, Jenista ER, Wendell DC, Azevedo CF, Campbell MJ, Darty SN, et al. Patients With Acute Myocarditis Following mRNA COVID-19 Vaccination. JAMA Cardiology. 2021 Oct 1;6(10).

18. Muthukumar A, Narasimhan M, Li Q-Z, Mahimainathan L, Hitto I, Fuda F, et al. In-Depth Evaluation of a Case of Presumed Myocarditis After the Second Dose of COVID-19 mRNA Vaccine. Circulation. 2021 Aug $10 ; 144(6)$.

19. Abu Mouch S, Roguin A, Hellou E, Ishai A, Shoshan U, Mahamid L, et al. Myocarditis following COVID-19 mRNA vaccination. Vaccine. 2021 Jun;39(29).

20. Larson KF, Ammirati E, Adler ED, Cooper LT, Hong KN, Saponara G, et al. Myocarditis after BNT162b2 and mRNA-1273 Vaccination. Circulation. 2021;506-8.

21. Marshall M, Ferguson ID, Lewis P, Jaggi P, Gagliardo C, Collins JS, et al. Symptomatic Acute Myocarditis in 7 Adolescents After Pfizer-BioNTech COVID-19 Vaccination. Pediatrics. 2021 Sep;148(3).

22. Albert E, Aurigemma G, Saucedo J, Gerson DS. Myocarditis following COVID-19 vaccination. Radiology Case Reports. 2021 Aug;16(8).

23. Bautista García J, Peña Ortega P, Bonilla Fernández JA, Cárdenes León A, Ramírez Burgos L, Caballero Dorta E. Acute myocarditis after administration of the BNT162b2 vaccine against COVID-19. Revista Española de Cardiología (English Edition). 2021 Sep;74(9).

24. Rosner CM, Genovese L, Tehrani BN, Atkins M, Bakhshi H, Chaudhri S, et al. Myocarditis Temporally Associated With COVID-19 Vaccination. Circulation. 2021 Aug 10;144(6). 
25. Ammirati E, Cavalotti C, Milazzo A, Pedrotti P, Soriano F, Schroeder JW, et al. Temporal relation between second dose BNT162b2 mRNA Covid-19 vaccine and cardiac involvement in a patient with previous SARSCOV-2 infection. IJC Heart \& Vasculature. 2021 Jun;34.

26. McLean K, Johnson TJ. Myopericarditis in a previously healthy adolescent male following COVID-19 vaccination: A case report. Academic Emergency Medicine. 2021 Aug 21;28(8).

27. D’Angelo T, Cattafi A, Carerj ML, Booz C, Ascenti G, Cicero G, et al. Myocarditis After SARS-CoV-2 Vaccination: A Vaccine-Induced Reaction? Canadian Journal of Cardiology. 2021 Jun;

28. Snapiri O, Rosenberg Danziger C, Shirman N, Weissbach A, Lowenthal A, Ayalon I, et al. Transient Cardiac Injury in Adolescents Receiving the BNT162b2 mRNA COVID-19 Vaccine. Pediatric Infectious Disease Journal. 2021 Oct 2;40(10).

29. Mansour J, Short RG, Bhalla S, Woodard PK, Verma A, Robinson X, et al. Acute myocarditis after a second dose of the mRNA COVID-19 vaccine: a report of two cases. Clinical Imaging. 2021 Oct;78.

30. Minocha PK, Better D, Singh RK, Hoque T. Recurrence of Acute Myocarditis Temporally Associated with Receipt of the mRNA Coronavirus Disease 2019 (COVID-19) Vaccine in a Male Adolescent. The Journal of Pediatrics. 2021 Nov;238.

31. Wang J, Han B. Dysregulated CD4+ T Cells and microRNAs in Myocarditis. Frontiers in Immunology. 2020 Mar 25;11.

32. Corsten MF, Papageorgiou A, Verhesen W, Carai P, Lindow M, Obad S, et al. Molecular Medicine MicroRNA Profiling Identifies MicroRNA-155 as an Adverse Mediator of Cardiac Injury and Dysfunction During Acute Viral Myocarditis. 2012; Available from:

http://circres.ahajournals.org/lookup/suppl/doi:10.1161/CIRCRESAHA.112.

33. Babar IA, Cheng CJ, Booth CJ, Liang X, Weidhaas JB, Saltzman WM, et al. Nanoparticle-based therapy in an in vivo microRNA-155 (miR-155)-dependent mouse model of lymphoma. Proceedings of the National Academy of Sciences. 2012 Jun 26;109(26).

34. Yang L, Wang B, Zhou Q, Wang Y, Liu X, Liu Z, et al. MicroRNA-21 prevents excessive inflammation and cardiac dysfunction after myocardial infarction through targeting KBTBD7. Cell Death \& Disease. 2018 Jul $10 ; 9(7)$.

35. Wu J, Shen L, Chen J, Xu H, Mao L. The role of microRNAs in enteroviral infections. The Brazilian Journal of Infectious Diseases. 2015 Sep;19(5).

36. Krützfeldt J, Rajewsky N, Braich R, Rajeev KG, Tuschl T, Manoharan M, et al. Silencing of microRNAs in vivo with 'antagomirs.' Nature. 2005 Dec 30;438(7068).

37. He J, Yue Y, Dong C, Xiong S. MiR-21 confers resistance against CVB3-induced myocarditis by inhibiting PDCD4-mediated apoptosis. Clinical \& Investigative Medicine. 2013 Apr 1;36(2).

38. Xu H-F, Gao X-T, Lin J-Y, Xu X-H, Hu J, Ding Y-J, et al. MicroRNA-20b suppresses the expression of ZFP-148 in viral myocarditis. Molecular and Cellular Biochemistry. 2017 May 28;429(1-2).

39. Zhu P, Chen S, Zhang W, Duan G, Jin Y. Essential Role of Non-Coding RNAs in Enterovirus Infection: From Basic Mechanisms to Clinical Prospects. International Journal of Molecular Sciences. 2021 Mar 12;22(6).

40. Zhang Y, Wang Z, Gemeinhart RA. Progress in microRNA delivery. Journal of Controlled Release. 2013 Dec;172(3). 
41. Zhang Y, Zhang M, Li X, Tang Z, Wang X, Zhong M, et al. Silencing MicroRNA-155 Attenuates Cardiac Injury and Dysfunction in Viral Myocarditis via Promotion of M2 Phenotype Polarization of Macrophages. Scientific Reports. 2016 Mar 2;6(1).

42. Wang Y, Ma W, Lu S, Yan L, Hu F, Wang Z, et al. Androgen receptor regulates cardiac fibrosis in mice with experimental autoimmune myocarditis by increasing microRNA-125b expression. Biochemical and Biophysical Research Communications. 2018 Nov;506(1).

43. Corsten MF, Heggermont W, Papageorgiou A-P, Deckx S, Tijsma A, Verhesen W, et al. The microRNA221/-222 cluster balances the antiviral and inflammatory response in viral myocarditis. European Heart Journal. 2015 Nov 7;36(42).

44. Fan. Altered exosomal miR-181d and miR-30a related to the pathogenesis of CVB3 induced myocarditis by targeting SOCS3 [Internet]. Available from: https://david.ncifcrf.gov/

45. Pan A, Tan Y, Wang Z, Xu G. STAT4 silencing underlies a novel inhibitory role of microRNA-141-3p in inflammation response of mice with experimental autoimmune myocarditis. Am J Physiol Heart Circ Physiol [Internet]. 2019;317:531-40. Available from: http://starbase.sysu.edu.cn/

46. Chen X, Dong S, Zhang N, Chen L, Li M-G, Yang P-C, et al. MicroRNA-98 plays a critical role in experimental myocarditis. International Journal of Cardiology. 2017 Feb;229.

47. Skalsky RL, Cullen BR. Viruses, microRNAs, and Host Interactions. Annual Review of Microbiology. 2010 Oct $13 ; 64(1)$.

48. Li X, Zou X. An overview of RNA virus-encoded microRNAs. ExRNA. 2019 Dec 8;1(1).

49. Mishra R, Kumar A, Ingle H, Kumar H. The Interplay Between Viral-Derived miRNAs and Host Immunity During Infection. Frontiers in Immunology. 2020 Jan 23;10.

50. Ong J, Woldhuis RR, Boudewijn IM, van den Berg A, Kluiver J, Kok K, et al. Age-related gene and miRNA expression changes in airways of healthy individuals. Scientific Reports. 2019 Dec 6;9(1).

51. Rohani N, Ahmadi Moughari F, Eslahchi C. DisCoVering potential candidates of RNAi-based therapy for COVID-19 using computational methods. PeerJ. 2021 Feb 26;9.

52. Fani M, Zandi M, Ebrahimi S, Soltani S, Abbasi S. The role of miRNAs in COVID-19 disease. Future Virology. 2021 Apr;16(4).

53. Farr RJ, Rootes CL, Rowntree LC, Nguyen THO, Hensen L, Kedzierski L, et al. Altered microRNA expression in COVID-19 patients enables identification of SARS-CoV-2 infection. PLOS Pathogens. 2021 Jul 28;17(7).

54. Täubel J, Hauke W, Rump S, Viereck J, Batkai S, Poetzsch J, et al. Novel antisense therapy targeting microRNA-132 in patients with heart failure: results of a first-in-human Phase $1 \mathrm{~b}$ randomized, double-blind, placebo-controlled study. European Heart Journal. 2021 Jan 7;42(2).

55. Yun S-H, Shin H-H, Ju E-S, Lee Y-J, Lim B-K, Jeon E-S. Inhibition of RNA Helicase Activity Prevents Coxsackievirus B3-Induced Myocarditis in Human iPS Cardiomyocytes. International Journal of Molecular Sciences. 2020 Apr 25;21(9).

56. Lambert M-P, Terrone S, Giraud G, Benoit-Pilven C, Cluet D, Combaret V, et al. The RNA helicase DDX17 controls the transcriptional activity of REST and the expression of proneural microRNAs in neuronal differentiation. Nucleic Acids Research. 2018 Sep 6;46(15).

\section{Figures}




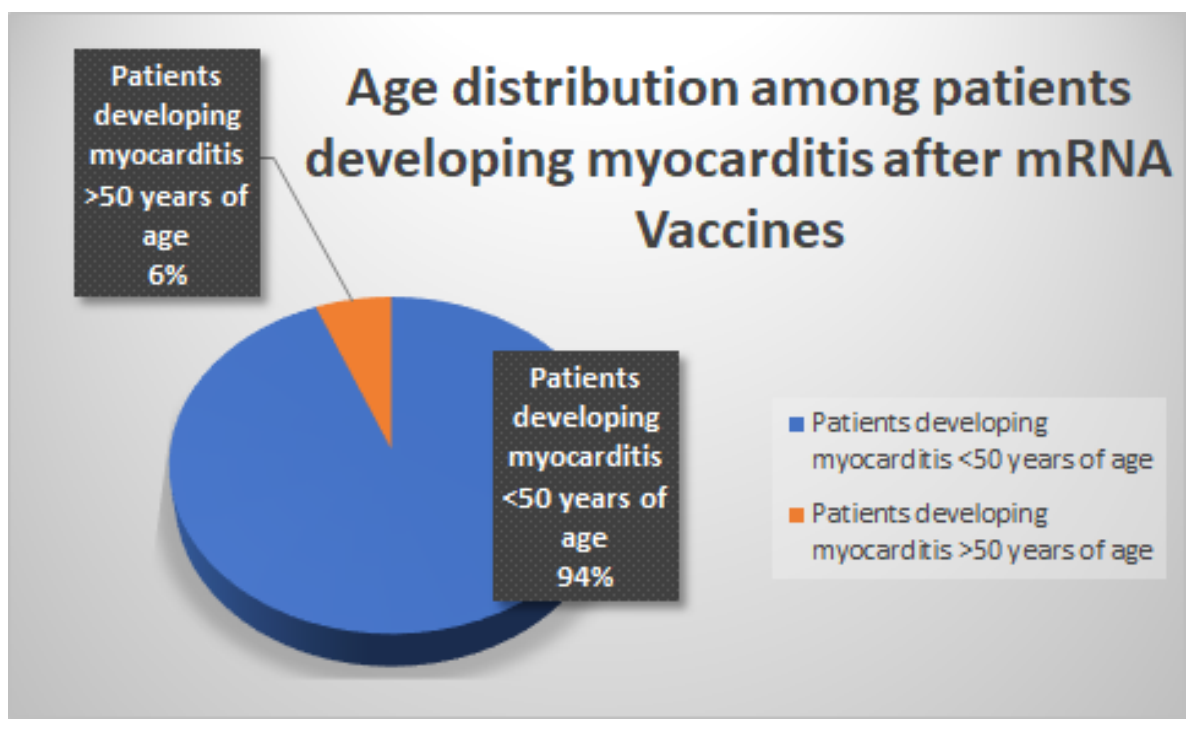

\section{Figure 1}

Age Distribution among patients developing myocarditis after mRNA-based COVID-19 vaccines Abbreviations: COVID-19: Coronavirus disease 2019, mRNA: messenger Ribonucleic acid

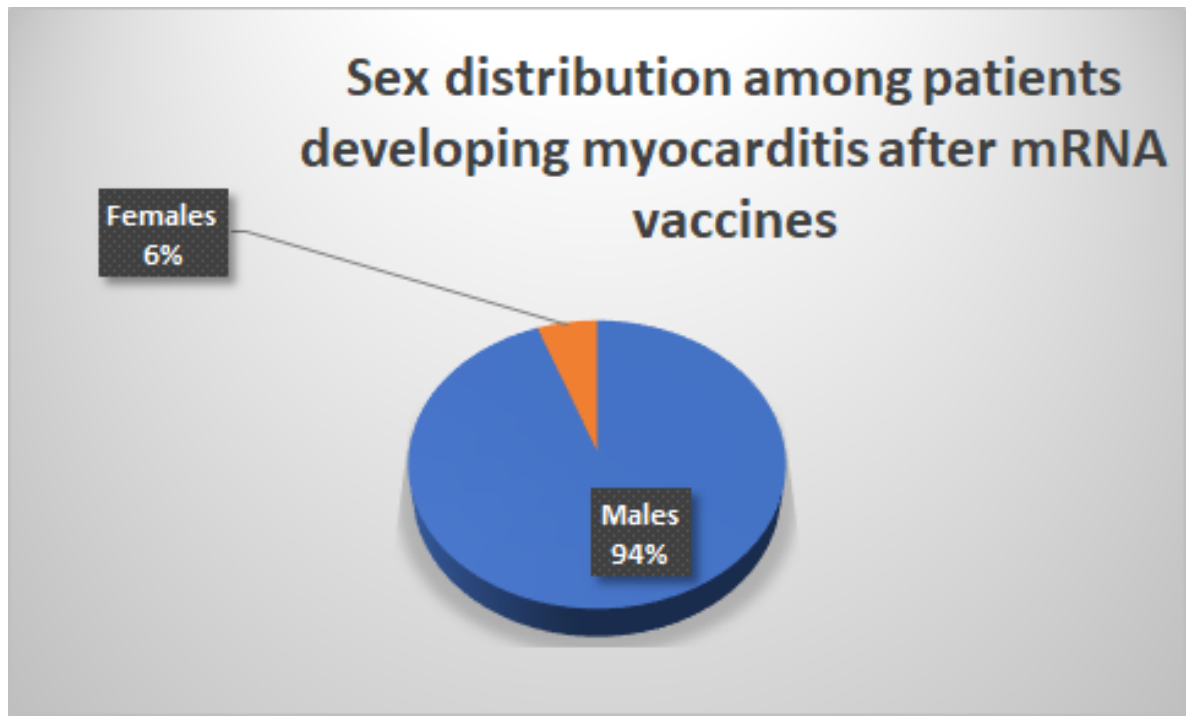

\section{Figure 2}

Sex Distribution among patients developing myocarditis after mRNA-based COVID-19 vaccines Abbreviations: COVID-19: Coronavirus disease 2019, mRNA: messenger Ribonucleic acid 


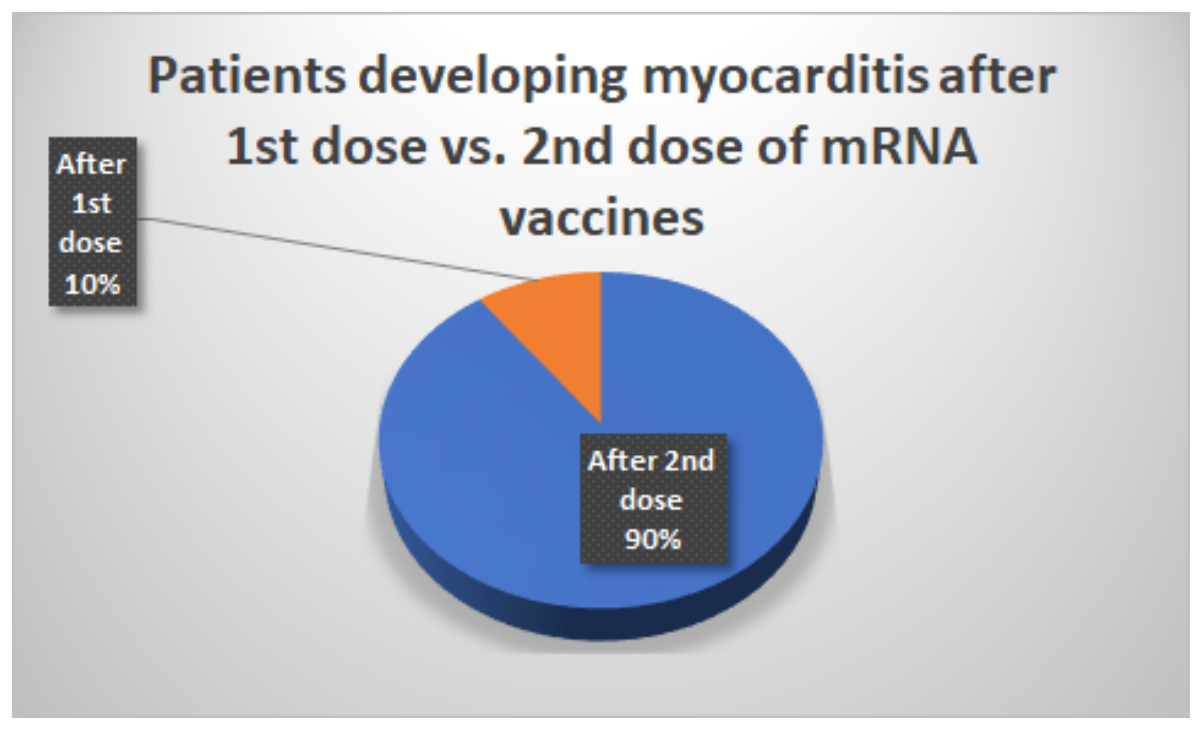

Figure 3

Patients developing myocarditis after 1st dose vs. 2nd dose of mRNA-based COVID-19 vaccines Abbreviations: COVID-19: Coronavirus disease 2019, mRNA: messenger Ribonucleic acid 


\section{THE POTENTIAL ROLE OF MICRO RNAS IN mRNA VACCINES' MYOCARDITIS}

\section{mRNA}

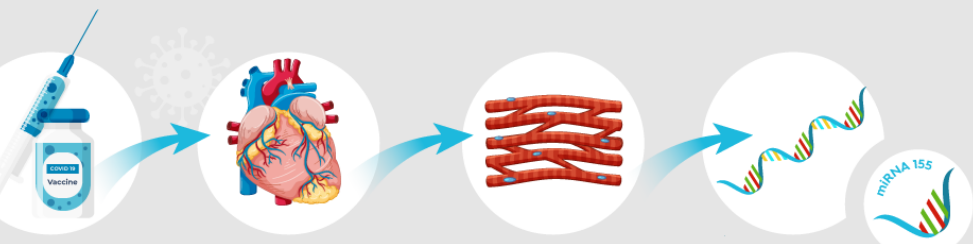

mRNA vaccines might Interact with human cellular machinery to upregulate certain micro RNAs, notably miRNA 155 which causes myocarditis
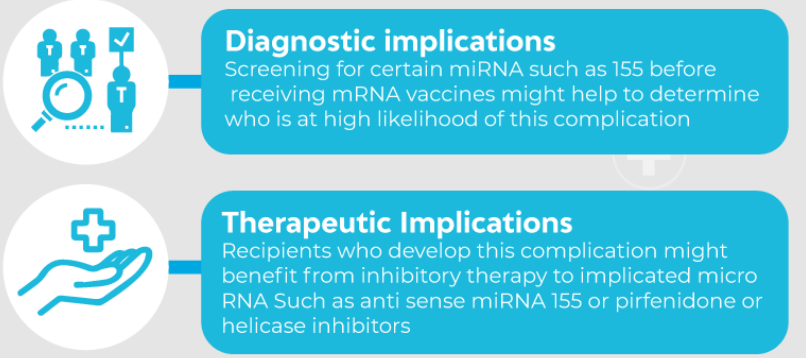

\section{Why are most cases below the age of $50 ?$}

Due to loss of muscle mass after age of of 50 with subsequent reduction of key micro RNAs such as 155 being highly expressed in muscles

Sarcopenia Index can be used to stratify recipents of mRNA vaccine -The lower the index the lower the muscle mass, the lower the liklihood of myocarditis from mRNA vaccines.

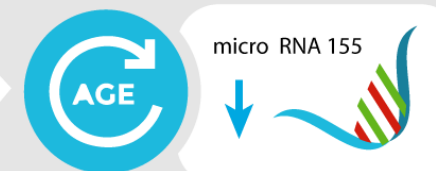

Sarcopenia
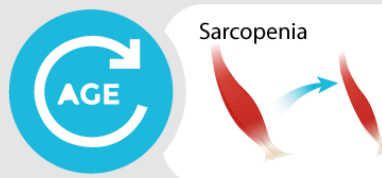

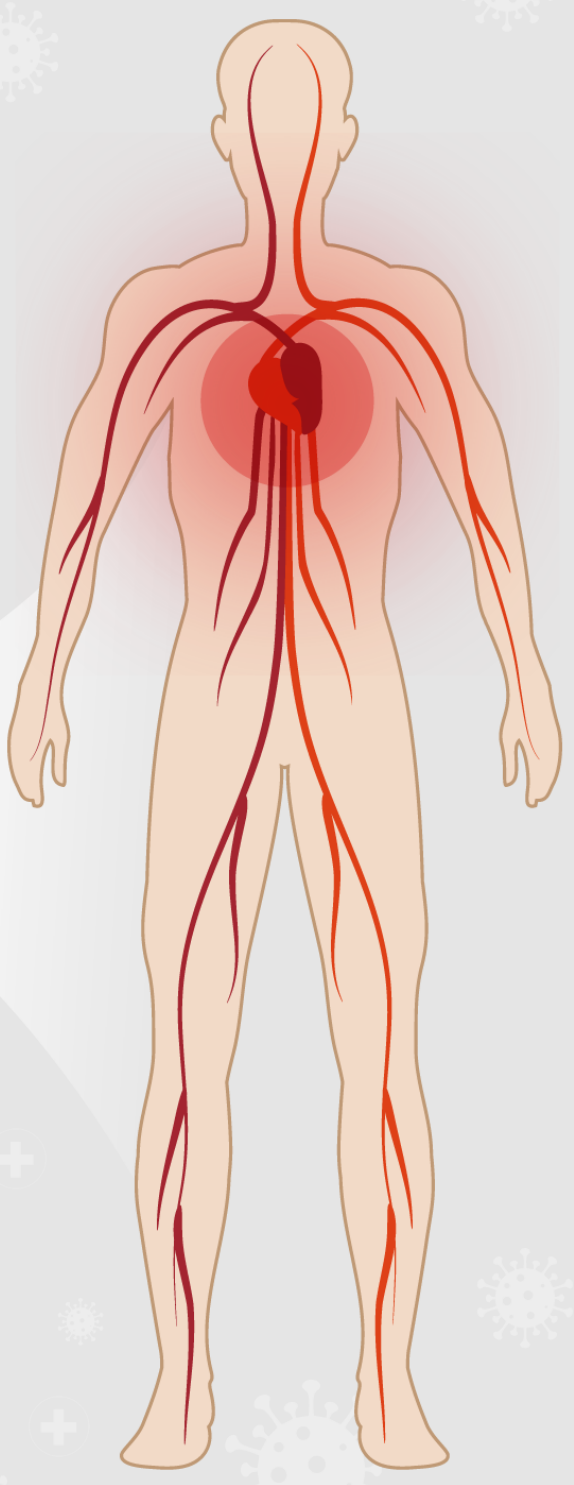

\section{Figure 4}

The potential role of micro-RNAs in mRNA-based vaccines Abbreviations: COVID-19: Coronavirus disease 2019, mRNA: messenger Ribonucleic acid, miRNA: Micro Ribonucleic acid 